\title{
EFFECT OF ANABAENA AZOLLAE ON FISH QUALITY, NUTRITIVE COMPONENTS AND ITS ANTIBACTERIAL ACTION ON AEROMONAS HYDROPHILA.
}

\author{
BARAKAT M.*; NEHAD I.E. SALEM ${ }^{* *}$; AMAL M.A. KHALIFA ${ }^{* * *}$; HALA A.M. ABD-EL- \\ HADY $^{* * *}$ and MONA E. ABASS*
}

*Biochemistry department, Animal Health Research Institute -Kafrelshikh, Egypt.

${ }^{* *}$ Food Hygiene department, Animal Health Research Institute -Kafrelshikh, Egypt.

*** Microbiology department, Animal Health Research Institute -Kafrelshikh, Egypt.

Email: mmbarakat2003@gmail.com

Assiut University Email: www.aun.edu.eg

\section{ABSTRACT}

Received at: $3 / 2 / 2015$

Accepted: 24/2/2015
A total of 60 of Tilapia nilotica fish brought from El-khashea farm in kafr El-sheikh governorate in plastic cage to Animal Health Institute. Then fish were divided into 3 groups in 3 glass aquarium each one contain 20 fish (Nile tilapia). The fish were fed on the experimental diets during 6 weeks of the experimental period. Fish were fed during the acclimation period on an artificial basal ration at a rate of $3 \%$ of the body weight 1 meal daily. Fish in the first group fed on non supplemented control diet while, fish in the second and third groups $\left(\mathrm{A}_{1}, \mathrm{~A}_{2}\right)$ fed on diets supplemented with 10 $\& 15 \%$ Anabaena azollae respectively. The control, first and second experimental groups $\left(\mathrm{A}_{1}, \mathrm{~A}_{2}\right)$ was infected with A.hydrophila by using concentrate $1 \times 10^{6} \mathrm{cfu} / \mathrm{gm}$. This experiment was designed to study the effect of Anabaena azollae on fish quality, chemical composition of fish including moisture, crude protein, carbohydrates, fat and ash as well as its antibacterial action on A.hydrophila. In control group the bacterial count of A.hydrophila was ranged from $2 \times 10^{5}$ to $4 \times 10^{5}$ with mean value $3 \times 10^{5} \pm 1 \times 10^{4} \mathrm{cfu} / \mathrm{gm}$, In group $\left(\mathrm{A}_{1}\right)$ the count of A.hydrophila was ranged from $1 \times 10^{4}$ to $2 \times 10^{5}$ with mean value $2 \times 10^{4} \pm 1 \times 10^{4} \mathrm{cfu} / \mathrm{gm}$, In group $\left(\mathrm{A}_{2}\right)$ the count of A.hydrophila was ranged from $1 \times 10^{2}$ to $1 \times 10^{4}$ with mean value $2 \times 10^{3} \pm 1 \times 10^{3} \mathrm{cfu} / \mathrm{gm}$. In vitro sensitivity test showed that the anabaena has antibacterial effect on A.hydrophila by 2 concentrations $10 \%$ and $15 \%$ with inhibition zone 0.8-0.9 mm respectively. Chemical composition of fish in the control group showed mean values for carbohydrates, protein, fat, ash and moisture as $0.9 \pm 0.07,19.9 \pm 0.3,2.9 \pm 0.14,1.8 \pm 0.09$ and $73.25 \pm 0.2 \%$ respectively. The mean values of carbohydrates, protein, fat, ash and moisture in first group $\left(\mathrm{A}_{1}\right)$ were $0.76 \pm 0.09,21.3 \pm 0.3,2.68 \pm 0.1,1.58 \pm 0.16$ and $72.9 \pm 0.3 \%$ respectively. Chemical composition percentage $(\%)$ of fish in the second group $\left(\mathrm{A}_{2}\right)$ were $0.73 \pm 0.07$, $21.5 \pm 0.3,2.4 \pm 0.19,1.63 \pm 0.1$ and $72.48 \pm 0.31$ for carbohydrates, protein, fat, ash and moisture respectively. So, the mean of A.hydrophlila count decrease gradually from control group to group $\mathrm{A}_{1}$ with Anabeana $10 \%$ to group $\mathrm{A}_{2}$ with Anabeana $15 \%$. In addition the mean of moisture carbohydrate $\%$ and fat $\%$ decreases gradually from control group to group $\mathrm{A}_{1}$ to group $\mathrm{A}_{2}$. While the mean of protein $\%$ increase gradually from control group to group $A_{1}$ to group $A_{2}$. In addition the mean of ash $\%$ decrease from control group to group $A_{1}$ to group $A_{2}$.

Key words: Anabaena azollae, Fish quality, Aeromonas hydrophila.

\section{INTRODUCTION}

Food is considered as an important ecological factor influencing the population dynamics of fishes. Recently the utilization of aquatic plants having high food value are used to supplement fish food has taken a new dimension for producing the much required animal protein at low cost Lakshmanan et al. (1967).
While fishing must surely be one of the oldest recorded sources of livelihood it is only comparatively recently that fish have become important components of the diets of the majority of the world's people especially those living in developing countries. Consumption of fish and seafood products reached 14 Kilograms per capita in developing countries in 2001, nearly twice the level 
recorded in the early 1970 s, while population in those countries doubled over the same period. Fish are an important component of the growth rapid of the consumption of animal products in developing countries over the past two decades and into the foreseeable future Christopher et al. (2003).

Fish provides a good source of high quality protein and contains many vitamins and minerals. It may be classed as either white fish and oily or shellfish. As a result of its high fat content, fish contain a range of fat-soluble vitamins (A, D, E and $\mathrm{K}$ ) and essential fatty acids particularly the omega 3 which are heartfriendly and can make improvements in brain development and reproduction., all of which are vital for the healthy functioning of the body. Especially people with cardiovascular diseases Fellows and Hampton, (1992).

Fish are susceptible to a wide variety of bacterial pathogens, many of these bacteria capable of causing disease are considered by some to be saprophytic in nature Toranzo et al. (2005). These bacteria only become pathogens when fishes are physiologically unbalanced, nutritionally deficient, or there are other stressors, i.e., poor water quality, overstocking, which allow opportunistic bacterial infections to precede Anderson, (1995). From these pathogens Aeromonas hydrophila which is primarily known as a fish pathogen but can also be pathogenic in humans and amphibians due to a tissue damaging enterotoxin. Some strains of $A$. hydrophila are capable of causing illness in fish including tail rot, fin rot, hemorrhagic septicemia, scale protrusion disease, and ulcer disease primarily in freshwater fish. Also it causes illness in amphibians as well as in humans who may acquire infections through open wounds or by ingestion of a sufficient count of the organisms in food or in water Microbe Wiki, (2007).

Chopra and Houston, (1999) illustrates that Aeromonas hydrophila is more harmful than was previously believed. It is resistant to many common antibiotics such as penicillin and ampicillin. Also resistant to refrigeration and able to grow at low temperatures. It can also thrive at warmer temperatures, and growing at 37 degrees Celsius as well as it can live at 25 degrees Celsius. In addition its resistsntance to chlorine.

Aeromonas hydrophila can be found in aquatic environments as well as in food, and can be found worldwide. It can cause both intestinal and non intestinal infections in humans, and can often be fatal. Some of the diseases that Aeromonas hydrophila and other Aeromonas species can cause illness include: septicemia, meningitis, pneumonia, and gastroenteritis Albert et al. (2000).
In humane the bacterium is transmitted through fecaloral transmission, contact with contaminated water, food, soil, feces, and ingestion of contaminated fish or reptiles. The most common way of catching the bacterium is through an open wound in contaminated water. The mild symptoms of the infection include fever and chills. The people that have the infection and it becomes septic, the symptoms include abdominal pain, nausea, vomiting, and diarrhea HCMSDS, (2004).

Anabaena azolae is a small filamentous phototrophic cyanobacteria generally seen as a multicellular organism with two distinct, interdependent cell types. The first performs oxygenic photosynthesis and is typically blue green in color and the second fix atmospheric nitrogen. Azolae have formed a symbiotic relationship in which the Cyanobacterium receives carbon and nitrogen sources from the plant in exchange for fixed nitrogen. This relationship has proven to be useful to humans in the production of food. Microbe Wiki, (2011). Because Azolae has a higher crude protein content and also favorable essential amino acid (EAA) composition for animal nutrition (rich in lysine), it attracted the attention of livestock, poultry and fish farmers. Azolae grows in association with the blue green algae Anabaena azalea, is perhaps the most promising from the point of view of cultivation productivity and nutritive value Lumpkin and Plucknett, (1982).

New antibacterial agent with high activity and without side effects for human and for environment are therefore urgently needed. Some cyanobacterial species could be a prolific resource for substances with antibacterial activity. Therefore, the main objective of the present study was to investigate the antibacterial activity of cyanobacterial species against species belonging to genus Aeromonas and also to determine the value of Azolae in Nile Tilapia nutrition as a protein source in compounded diets.

\section{MATERIALS and MEATHODS}

\section{Collection of samples:}

A total of 60 fish Tilapia nilotica brought from Elkhashea farm in kafr El-sheikh governorate in plastic bags to Animal Health Institute. Then the fish were divided into 3 groups in 3 glass aquarium each one contain 20 fish (Nile tilapia). Fish in the first group fed on non supplemented control diet while, fish in the second and third groups $\left(\mathrm{A}_{1}, \mathrm{~A}_{2}\right)$ fed on diets supplemented with $10 \& 15 \%$ Anabaena azollae respectively. The control, first and second experimental groups $\left(\mathrm{A}_{1}, \mathrm{~A}_{2}\right)$ was infected with $\mathrm{A}$. hydrophila by using concentrate $1 \times 10^{6} \mathrm{cfu} / \mathrm{gm}$. All collected fish were subjected to the following examinations: 


\section{1- Bacteriological Examination:}

Total Aeromonas hydrophila count according to APHA (1992):

One gram was taken from each examined fish, make serial dilution on peptone water then Aeromonas hydrophila was counted on differential media (Aeromonas Pseudomonas agar) by using plate surface spreading technique then incubate it at $37^{\circ} \mathrm{c}$ for 24 hours.

\section{2- Sensitivity test according to (Neveen and Ibraheem, 2008)}

The anabaena desks with concentration (10-15) \% from Kafrelsheikh fungal institute. The Aeromonas hydrophila was incubated in nutrient broth tube for 24 hours at $37^{\circ} \mathrm{C}$ then spread on nutrient agar plate for the sensitivity test and incubated at $37^{\circ} \mathrm{C}$ for 24 hours.

\section{3- Chemical Examination:}

The examined samples of fish flesh were analyzed to determine of moisture, protein, fat, ash and carbohydrate by using the standard method recommended by Association of Official Analytical Chemists "AOAC" (2000) as follow:

\section{Determination of moisture $\%$ according to} (AOAC, 2000):

A dish was dried in an oven and cooled in the desiccators. Approximately $2 \mathrm{~g}$ of sample were weighed into the dish and dried in the oven at $102^{\circ} \mathrm{C}$ with the lid alongside for 2 hours. The dish was covered with the lid, and transferred to the desiccators and when the dish completely cooled, it was weighed, then heated in the oven half-an-hour and re- weighed. Repeat until successive weights do not differ.

$$
\text { Moisture } \%=\frac{\text { Weight lost } x 100}{\text { Weight of sample }}
$$

\section{Determination of protein $\%$ according to (AOAC, 2000):}

The weighed samples were placed in Kjeldahl flask containing mercury oxide (catalyst) and potassium sulphate (increasing boiling point). Concentrated sulphuric acid was added, and the mixture was heated and boiled until the sample was completely digested and yielded ammonia. The flask was cooled, the solidified content (including a sulphide to precipitate the mercury) was added and, the released ammonia was distilled via a condenser into a boric acid solution containing acid-base indicator. The collected ammonia was titrated with standardized hydrochloric acid. So the amount of ammonia present could be detected, and thus the amount of nitrogen can be calculated.

Crude protein $=$ nitrogen $x$ 6.25.

\section{Determination of fat $\%$ according to (AOAC,} 2000):

A weighed sample was dried at $60{ }^{\circ} \mathrm{C}$ for 72 hours. The dried sample was exactly weighed and wrapped carefully in a filter paper. Such prepared sample was used in determination of fat $\%$.

Soxhlet flask containing $75 \mathrm{ml}$ ether was placed on the electrical heater; the sample was placed in the extractor which was fixed tightly over the Soxhlet flask. Then, the condenser was fixed over the extractor. When heating occurred ether will be evaporated and raised up through the outside capillary tube to the condenser, where it was re-condensed to liquid again under the effect of water current in the condenser, and down set on the sample dissolving apart of the fat. Ether was accumulated in the extractor until siphoning occurred where the ether returned to the flask again with the dissolved fat. This process was repeated until all fat in the sample will be extracted this take about 6 hours. Repeat weighing the sample after drying to record the loss of weight and calculate fat $\%$.

\section{Determination of ash \% according to (AOAC, 2000):}

A weighed sample was dried at $60{ }^{\circ} \mathrm{C}$ for 72 hours. In a porcelain crucible of known weight, the known weight of dried sample was placed and the crucible was transferred into muffle furnace at $450^{\circ} \mathrm{C}$ to free ash from carbon and inorganic matters. The process was continued for about 6 hours then the crucible was cooled, desiccated and weighed. This technique of heating and weighing was repeated several times till reaching 2 equal successive weights. Therefore, the ash \% was calculated as follow:

$$
\% \text { Ash }(\text { wet })=\frac{(\text { wt. crucible and ash }- \text { wt. crucible })}{(\text { wt. crucible and sample }- \text { wt. crucible) }}
$$

\section{Determination of Carbohydrate \% according to} (AOAC, 2000):

Each sample was estimated for its moisture, protein, fat, crude fiber and ash content. Accordingly, carbohydrate $\%$ was calculated by the difference from the following equation:

\section{Carbohydrate $\%=100-($ moisture $\%+$ protein $\%+$ fat $\%+$ ash $\%$ ).}

Anabaena azolae contains $20-25.5 \%$ protein, $3.1 \%$ fat, $34.9 \%$ carbohydrate, $8.5-11.7 \%$ cellulose and rich in essential amino acids. Murty, (1986).

6. Statistical analysis:

It was performed by run on the computer using the SAS program (SAS, 1998). 


\section{RESULTS}

Table 1: The A.hydrophila analysis of fish samples (60).

\begin{tabular}{cccc}
\hline & Min & Max & Mean \pm SE \\
\hline Control & $2 \times 10^{5}$ & $4 \times 10^{5}$ & $3 \times 10^{5} \pm 1 \times 10^{4 \mathrm{a}}$ \\
\hline $\mathbf{A 1}$ & $1 \times 10^{4}$ & $2 \times 10^{5}$ & $2 \times 10^{4} \pm 1 \times 10^{4 \mathrm{~b}}$ \\
\hline $\mathbf{A 2}$ & $1 \times 10^{2}$ & $1 \times 10^{4}$ & $2 \times 10^{3} \pm 1 \times 10^{3 \mathrm{c}}$ \\
\hline
\end{tabular}

Means in the same column with different small litters are significantly different at $(\mathrm{p} \leq 0.05)$

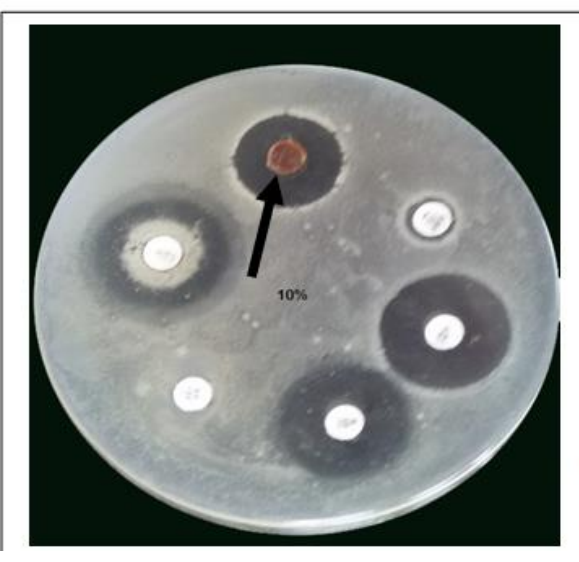

$10 \%$

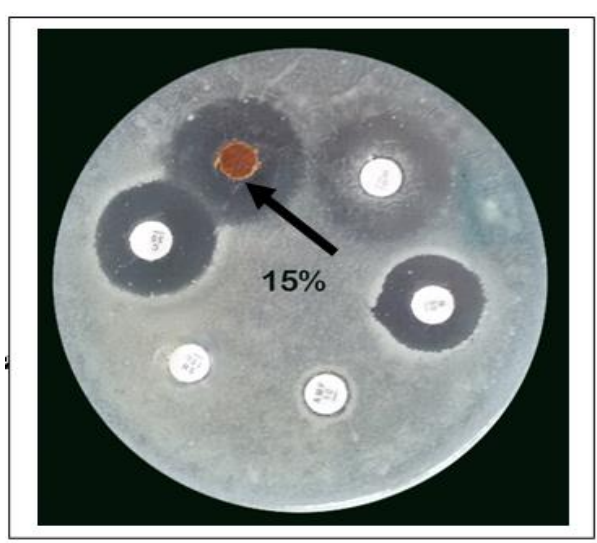

$15 \%$

Figure 1: sensitivity test of anabaena (10-15) \% against A.hydrophila.

Table 2: The chemical analysis of fish samples.

\begin{tabular}{|c|c|c|c|c|c|c|c|c|c|}
\hline & \multicolumn{3}{|c|}{ Moisture } & \multicolumn{3}{|c|}{ Fat } & \multicolumn{3}{|c|}{ Ash } \\
\hline & Min & $\operatorname{Max}$ & Mean \pm SE & Min & $\operatorname{Max}$ & Mean \pm SE & Min & $\operatorname{Max}$ & Mean $\pm S E$ \\
\hline Control & 72.1 & 74.9 & $73.25 \pm 0.32^{\mathrm{a}}$ & 2.3 & 3.5 & $2.9 \pm 0.14^{\mathrm{a}}$ & 1.4 & 2.2 & $1.8 \pm 0.09^{\mathrm{a}}$ \\
\hline A1 & 71.6 & 74.2 & $72.9 \pm 0.37^{\mathrm{a}}$ & 2.3 & 3.2 & $2.68 \pm 0.13^{\mathrm{a}, \mathrm{b}}$ & 1.1 & 2.1 & $1.58 \pm 0.16^{\mathrm{a}}$ \\
\hline A2 & 71.4 & 73.5 & $72.48 \pm 0.31^{\mathrm{a}}$ & 1.8 & 3 & $2.4 \pm 0.198^{\mathrm{b}}$ & 1.2 & 2 & $1.63 \pm 0.12^{\mathrm{a}}$ \\
\hline
\end{tabular}

Means in the same column with different small litters are significantly different at $(\mathrm{p} \leq 0.05)$

Table 3: The protein and carbohydrate values of fish samples.

\begin{tabular}{ccccccc} 
& \multicolumn{3}{c}{ Protein } & \multicolumn{3}{c}{ Carbohydrate } \\
\cline { 2 - 6 } & Min & Max & Mean \pm SE & Min & Max & Mean \pm SE \\
\hline Control & 18.8 & 21.4 & $19.9 \pm 0.3^{\mathrm{a}, \mathrm{b}}$ & 0.6 & 1.2 & $0.9 \pm 0.07^{\mathrm{a}}$ \\
\hline $\mathbf{A 1}$ & 20.1 & 22.3 & $21.3 \pm 0.3^{\mathrm{a}}$ & 0.5 & 1.1 & $0.76 \pm 0.09^{\mathrm{a}}$ \\
\hline $\mathbf{A 2}$ & 20.7 & 23.2 & $19 \pm 0.37^{\mathrm{b}}$ & 0.5 & 1 & $0.73 \pm 0.07^{\mathrm{a}}$ \\
\hline
\end{tabular}

Means in the same column with different small litters are significantly different at $(\mathrm{p} \leq 0.05)$ 


\section{DISCUSSION}

\section{1-Microbial examination:}

The results in Table (1) showed that the count of A.hydrophila in control group ranged from $2 \times 10^{5}$ to $4 \times 10^{5}$ with mean value $3 \times 10^{5} \pm 1 \times 10^{4} \mathrm{gm} / \mathrm{c}$ c.f.u. While in group $\left(\mathrm{A}_{1}\right)$ which has $10 \%$ Anabeana Azolae the count of A.hydrophila ranged from $1 \times 10^{4}$ to $2 \times 10^{5}$ with mean value $2 \times 10^{4} \pm 1 \times 10^{4} \mathrm{gm} / \mathrm{c}$ c.f.u. more over in group $\left(\mathrm{A}_{2}\right)$ which has $15 \%$ Anabeana Azolae the count of A.hydrophila ranged from $1 \times 10^{2}$ to $1 \times 10^{4}$ with mean value $2 \times 10^{3} \pm 1 \times 10^{3} \mathrm{gm} /$ c.f.u .So we notice that the mean value of A.hydrophila decrease gradually from control group to the second group, which mean that Anabeana Azolae has antibacterial effect against A.hydrophila. In vitro the sensitivity test for anabaena showed antibacterial effect against A. hydrophila at concentration of (10-15) \%. Similar results are recorded by Neveen and Ibraheem, (2008) they found that 10 species of genus Anabeana had antibacterial effect against 4 species of genus Aeromonas from which A. hydrophila. And also similar to Sabreen E. Fadl et al. (2013) who recorded that Nile Tilapia fed on Anabeana (10\%) recorded lower mortality rates $(11.11 \%)$ and zero mortality in Anabeana (15\%) compared to control (44.44\%). Bacterial fish diseases caused by Aeromonas species or other microorganisms lead every year to considerable economic losses in aquaculture. Antibiotic treatment of bacterial diseases in fish culture has been applied for years. The occurrence of antibiotic resistant bacteria associated with fish diseases is a worldwide problem in aquaculture, which has received considerable attention in the last years and continues to increase due to the absence of a more effective and safer use of antibiotics McPhearson et al. (1991); Smith et al. (1994). Also Honaucins, (2012) stated that, Cyanobacteria may possess the ability to produce substances that could one day serve as anti-inflammatory agents and combat bacterial infections in humans.

Some researchers believe A.hydrophila is a primary fish pathogen while others consider it only a secondary invader of already weakened fish. Environmental stress appears to be a likely inducer of disease outbreaks caused by $A$. hydrophila. Since $A$. hydrophila is naturally found in the fish gut, some stress or previously weakened state is usually necessary for a disease to develop. Proper care and optimal environmental conditions in hatcheries can help prevent outbreaks. A. hydrophila in humans is an opportunistic pathogen associated with blood infections, wound infections, and diarrhea. So two distinct types of gastroenteritis have been associated with A. hydrophila: A cholera-like illness with watery (rice and water) diarrhea and a dysenteric illness characterized by loose stools containing blood and mucus. Randy White, (1991).
Reports of wound infections have become more common recently and can cause severe tissue damage. Wound infections occurring mainly in people with weakened immune systems, and can be prevented by taking proper care of wounds, especially by not washing wounds with lake or river water. FDA (2006).

In general, people in developing countries are much more dependent on fish as part of their daily diets than those living in the developed world. Figures for 1995 show that while fish provide slightly over 7 percent of animal protein in North and Central America and more than 9 percent in Europe, in Africa they provide over 17 percent, in Asia over 26 percent, and in the low-income food-deficit countries (LIFDCs) including China they provide nearly 22 percent .Experts agree that, even in small quantities, fish can have a significant positive impact in improving the quality of dietary protein by complementing the essential amino acids that are often present in low quantities in vegetable-based diets. FAO, (1998).

\section{2- Chemical analysis:}

The results in table (2) showed that in control group the moisture \% ranged from 72.1 to 74.9 with mean value from $73.25 \pm 0.32$ the protein percent $\%$ ranged from 18.8 to 21.4 with mean value $19.9 \pm 0.3$, the fat $\%$ ranged from 2.3 to 3.5 with mean value $2.9 \pm 0.14$, the ash \% ranged from 1.4 to 2.2 with mean value $1.8+0.09$, the carbohydrate \% ranged from 0.6 to 1.2 with mean value $0.9 \pm 0.07$. These results were agree with Baz et al. (2014) who found that the mean value of moisture $\% 73.56$, protein $19.84 \%$, fat $\% 3.81$, ash $\%$ 2.35. These results attributed to farmed fish fed on ration contain high level of fat and ash and fish take long period of culturing till marketing and that cause increasing in body weight with increasing moisture, fat and protein percent. Muchiri and Nanua, (2006) aquaculture is recently playing an important role in the world fish production, and in 1990 it contributed about $10 \%$ of the total world fish production Tacon, (1993). Also aquaculture is one the fastest growing food production activities in the world FAO, (1997). Tilapias are considered the most important farmed fish in Egypt, since they represent about $52.8 \%$ of the total freshwater fish yield in Egypt GAFRED, (1996).

In the same table in group (A1) the results showed that The moisture \% ranged from 71.6 to 74.2 with mean value from $72.9 \pm 0.3$, the protein percent $\%$ ranged from 20.1 to 22.3 with mean value $21.3 \pm 0.3$, fat $\%$ ranged from 2.3 to 3.2 with mean value $2.68 \pm 0.1$, ash $\%$ ranged from 1.1 to 2.1 with mean value $1.58 \pm 0.16$, the carbohydrate $\%$ ranged from 0.5 to 1.1 with mean value $0.76 \pm 0.09$. While in group (A2) the results cleared that the moisture \% ranged from 71.4 to 73.5 with mean value from $72.48+0.3$, the protein percent $\%$ ranged from 20.7 to 23.2 with 
mean value $21.5+0.37$, fat $\%$ ranged from 1.8 to 3 with mean value $2.4 \pm 0.19$, ash \% ranged from 1.2 to 2 with mean value $1.63 \pm 0.1$, the carbohydrate \% ranged from 0.5 to 1 with mean value $0.73+0.07$. From the previous results we noticed that the moisture $\%$, fat $\%$, ash $\%$ and carbohydrate $\%$ decreased gradually from the control group to group $\left(A_{1}\right)$ to group $\left(A_{2}\right)$, while the protein \% increased gradually in the same groups. Fish require diets relatively higher in protein than those of commercially cultured animals. As protein represents the most expensive component in a formulated diet, it is considerable practical importance to determine the optimum level that will support maximum growth and survival.

As Fish is a food of excellent nutritional value, providing high quality protein and a wide variety of vitamins and minerals, Its protein - like that of meat is easily digestible and favourably complements dietary protein provided by cereals and legumes that are typically consumed in many developing countries. Experts agree that, even in small quantities, fish can have a significant positive impact in improving the quality of dietary protein by complementing the essential amino acids that are often present in low quantities in vegetable-based diets. FAO, (1998).

\section{REFERENCE}

Albert, M. John; Ashok K. Chopra and M. Sirajul Islam (2000): "Prevalence of Enterotoxin Genes in Aeromonas spp. Isolated from Children with Diarrhea, Healthy Controls, and the Environment." Journal of Clinical Microbiology, October, p. 3785-3790, Vol. 38, No. 10.

Anderson, DP. (1995): Novel techniques for fish disease diagnosis. In Diseases in Asian Aquaculture II. Eds Shariff M, Arther JR, Subasinghe RP. Fish Health Section. Asian Fish. Soc. Manilla, pp. 27-39.

AOAC (2000): Official Methods of Analysis: Association of Official Analytical Chemists, 16th edition. Maryland, USA.

APHA (1992): Standard Methods for the Examination of Dairy Products. American Public Health Association, Washington, D.C.

Baz, G.M.B.; Hanaa, F. Salama; Salwa, A.H. El-Fiky and Omnia (2014): A.Salah: Comparitive study on chemical properties of cultured and wild oreochromis niloticus.

Chopra, Ashok K. and Clifford W. Houston, (1999): "Enterotoxins in Aeromonas-associated gastroenteritis." Microbes and Infection; 1: 1129-1137.

Christopher L. Delgado; Nikolas Wada; Mark W. Rosegrant; Siet Meijer and Mahfuzuddin Ahmed (2003): Fish to 2020 supply and demand in changing Global Markets.
International Food Policy Research Institute and World Fish Center.

FAO (1997): Food and Agriculture Organization ' Aquaculture Production Statistics, 1986-1995. FAO Fish. Cire No. 815 Rev. 9Rome, Italy.

FAO, Rome, Italy (1998): The State of World Fisheries and Aquaculture. ISBN 92-5104187-3.

FDA (2006): Aeromonas hydrophila. 14 June 2006. U.S.- Bad Bug Book. 16 Mar. 2007. http://www.cfsan.fda.gov/ mow/chap17.html.

Fellows $P$ and Hampton A (Eds.) (1992): Fish and fish products Chapter 11 in: Small-scale food processing - A guide for appropriate equipment Intermediate Technology Publications, FAO, Rome. ISBN 185339 $\underline{1085}$.

GAFRED (Gen. Auth. Fish .Res. Develop. Egypt) (1996): Annual report for country fish production.

Health Canada, Material Safety Data SheetInfectious Substance, (2004): http://www.hcsc.gc.ca/pphb-dgspsp/msds-ftss/msds6e.html. February $3^{\text {th }}$, (HCMSDS, 2004) (C).

Honaucins, A.C. (2012): Potent Inhibitors of Inflammation and Bacterial Quorum Sensing: Synthetic Derivatives and Structure-Activity Relationships. Chemistry and Biology, 25: 14-20

Lakshmanan, M.A.V.; Murthy, D.S. and Pillai, K.K. and Banerjee (1967): On a new artificial feed for carp. fry. FAO Fisheries Report (44): 373: 373-387.

Lumpkin, T.A. and Plucknett, L. (1982): Azolla as a green manure: use and management in trop production. Westview press Boulder, Colorado. Westview Tropical Agriculture, series 15, 230p.

McPhearson, RM.; DePaola, A.; Zywno, SR.; Motes, ML Jr. and Guarino, AM. (1991): Antibiotic resistance in gram-negative bacteria from cultured catfish and aquaculture ponds. Aquaculture 99: 203-211. Moncheva P, Tishkov S, Dimitrova N, Hipeva V, AntonovaNikolova.

Microbe Wiki (2007): A Microbial Biorealm page on the genus Aeromonas http://microbewiki. kenyon.edu/index.php/Aeromonas.

Microbe Wiki. (2011): A Microbial Biorealm page on the Anabaena http://microbewiki.kenyon.edu/ index.php/Anabaena.

Muchiri, M. and Nanua, J. (2006): A comparison of nutritional value of farmed and wild Nile Tilapia. Aqua 2006.May 9-13, 2006, Florence, Italy.

Murty, A.S. (1986): Toxicity of pesticides to fish. Vols 1 and 11 C.R .C. Press Inc, 483, 355.

Neveen Abdel-Raouf and Ibraheem B.M. Ibraheem (2008): Antibiotic activity of two Anabaena species against four fish pathogenic 
Aeromonas species. African Journal of Biotechnology Vol. 7 (15), pp. 2644-2648, 4 August, 2008, Available online at http://www.academicjournals.org/AJB ISSN 1684-5315 (C) 2008 Academic Journals.

Randy White (1991): Aeromonas hydrophila, DVM, PhD Veterinary Pathologist, Newsletters.

Sabreen E. Fadl; Barakat, M. and Elgohary, $M$. (2013): Biochemical Studying of Anabaena (Cyanobacteria) On Nile Tilapia Alexandria Journal of Veterinary Sciences 2013, 39: 91-104

SAS Institute Inc. (SAS), (1998): SAS system for windows Statistical Software. SAS Institute Inc., Cary, North Carolina.
Smith, P.; Hiney, M. and Samuelsen, OB. (1994): Bacterial resistance to antimicrobial agents used in fish farming: a critical evaluation of method and meaning. Annu. Rev. Fish Dis. 4: 273-313.

Tacon, A.G.J. (1993): Feed ingredients for warm water fish. Fish meal and other processed feed stuffs. FAO Fish Cir., 856, FAO, Rome, Italy, $64 \mathrm{pp}$.

Toranzo, AE.; Beatriz, M. and Jesús, LR. (2005): A review of the main bacterial fsh diseases in mariculture systems. Aquaculture, 246: 1-4, 3761.

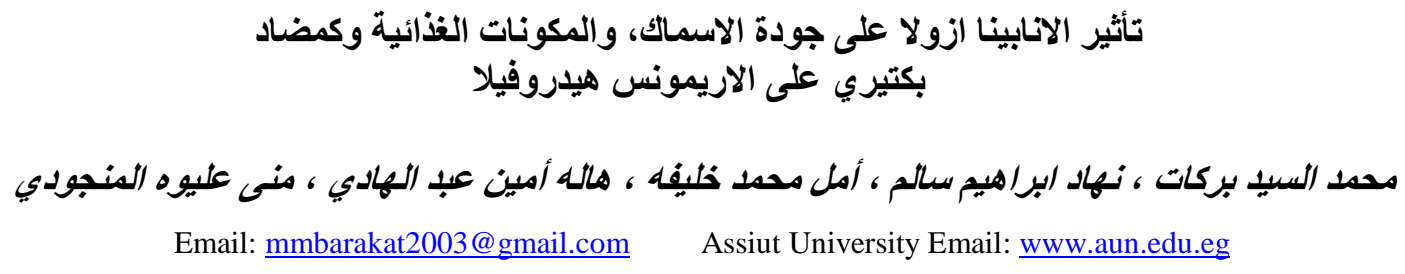

تم تجميع عدد •T سمكه بلطي نيلي من مزرعه الخاشعه في محافظة كفر الشيخ وتم نقلها في أقفاص بلاستيكيه لمعهد بحوث صحة

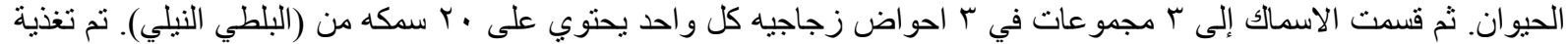

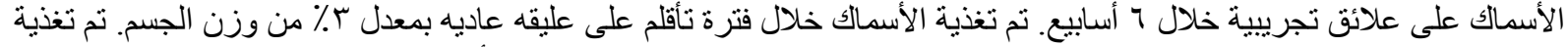

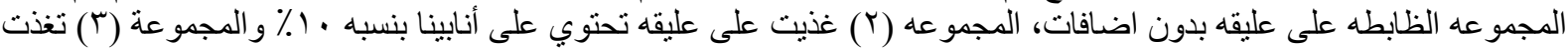



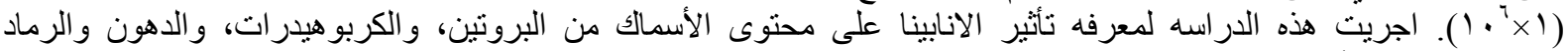

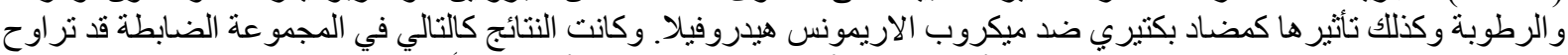

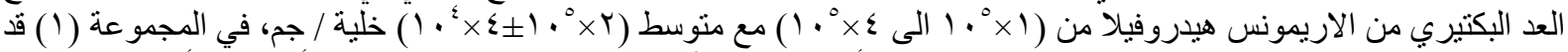

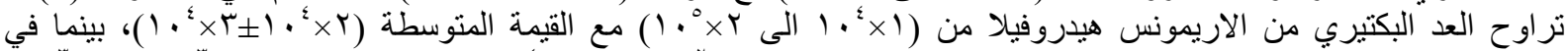



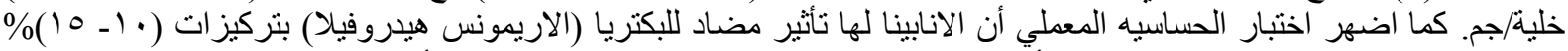

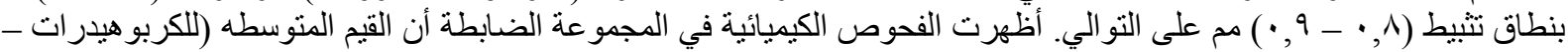




(

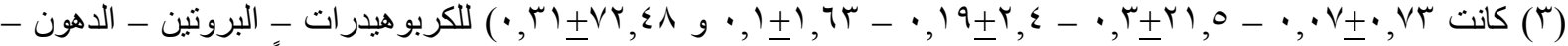

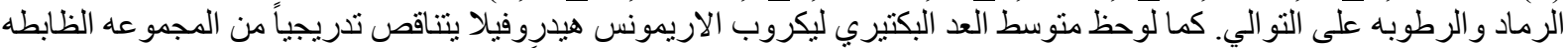

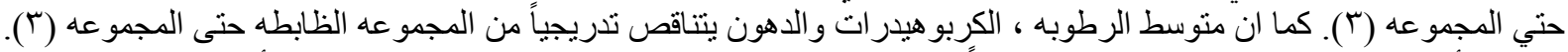

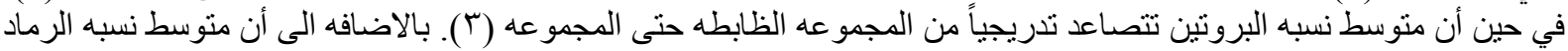

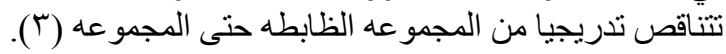

